\title{
Study on the Creative Strategy of Film and Television Culture under the Strategy of One Belt and One Road
}

\author{
Jing Wang \\ Xi'an Peihua University, Xi'an, Shaanxi, 710100
}

\begin{abstract}
One Belt and One Road is not only the road of economic development, but also carry the cultural memory along the country. The implementation of "One Belt and One Road" strategy should not only pay attention to economic exchanges, but also to promote the integration of Chinese culture and Silk Road national culture. The film and television products "going out" into the "One Belt and One Road" strategic overall layout, not only can bring some economic benefits, but also enhance the influence of Chinese film culture and improve the level of Chinese film and television culture industry.
\end{abstract}

Keywords: One Belt and One Road, film and television culture

\section{Introduction}

"One Belt and One Road" is short for "the Silk Road Economic Belt" and "the 21 st century Maritime Silk Road". In September and October 2013, President Xi Jinping proposed the strategic concept of "New Silk Road Economic Zone" and "21st Century Maritime Silk Road" respectively.

"One Belt and One Road" is not an entity and mechanism, but the concept of cooperation and development initiatives, is to rely on China and the relevant existing bilateral multilateral mechanism, with existing and effective regional cooperation platform, aimed at We should take the historic symbol of the ancient Silk Road, hold high the banner of peaceful development, take the initiative to develop the economic partnership with the countries along the lines, and jointly build the political community of mutual trust, economic integration, cultural 
inclusion, destiny and community of responsibility. "One Belt and One Road" initiative, for the world's largest charm, not only depends on how much investment and profits, more importantly, is to bring a new trend in the world, so that equality and cooperation, cultural exchanges, economic prosperity into the future another axis of the world order.

As we all know, the ancient Silk Road in Chinese main function is to trade, that is to strengthen the East-West economic ties. More than 2,100 years ago, the emperor of the Han dynasty made great efforts to open up the Silk Road on the land and the Silk Road on the sea, connecting China with many countries in Asia, Europe and Africa. Silk, porcelain and spices are in constant contact with each other. It is in the Silk Road, led by the world began to understand China, China began to affect the world. The Silk Road has played a very important role in promoting the exchange of ideas and culture between East and West, as well as the diversification of human civilization, and has made important contributions to the economic and cultural exchanges between the East and the West. Therefore, the ancient Silk Road, in addition to embody the human across the block, exchange mutual Kam's courage and perseverance, but also in the ancient EastWest civilization exchanges, exchanges in the history of writing an important chapter.

\section{The film and television culture and creative industry}

The film and television culture creative industry is closely related to the music industry, printing and electronic publishing, fashion and other industries across the film industry, radio and television industry, the network industry, video computer games and tourism industry. Hu Zhifeng, Li Jidong in the "Chinese three major issues of cultural and creative industries," that the film and television culture industry is an important part of cultural and creative industries, film and television industry development and prosperity to enhance the national cultural soft power and enhance Chinese external communication Force plays a decisive role. This paper discusses the three main problems of Chinese film and television culture creative industry; the problems of creativity, culture, industry are not big, there is no solution, and it is also the problem of Jiangxi film and TV culture industry. In the "thinking on a number of issues of film and television culture and creative industries," from the history, theory and reality of the three dimensions of film and television industry from industry to the process of industrialization, "is simply to enter a number of related industries integrated era, That is, from the cultural industry into a cultural industry, formed with economies of scale and scope of the economy, system and network of industrial groups. That is, the British public model, focusing on the art of film and television culture, education, and advocate the adoption of high-quality film and television products to inherit and carry forward the culture, to enhance the public's aesthetic ability and knowledge, and film and television culture as a Public services, film and television revenue does not depend on the market, but directly from the citizens to pay license fees or subsidies, that is not the basic ratings and box office 
revenue as the standard, relatively free from market and government The United States as the representative of the business model, the film and television products as consumer goods, pay attention to the commercial and entertainment film and television culture. Its income mainly by advertising, box office, extended product sales and other commercial activities, ratings and box office revenue has become an important evaluation criteria, rely on market mechanisms and government regulation to operate for consumers rather than for the citizens; to China and the former Soviet Union As the representative of the state model, the film and television products as promotional materials and works of art, emphasizing the ideological and cultural propaganda and cultural functions of cultural and artistic attributes, film and television institutions are often a government department, its revenue source mainly by financial allocation, Publicity and effectiveness of education and leadership satisfaction, do not value the ratings and box office revenue.

After more than 30 years of reform and opening up, Chinese film and television culture and creative industries belong to the state-owned mixed mode, in the ownership is dominated by state ownership, a variety of ownership coexist, and in the positioning of the property and function is presented as ideological propaganda, It is divided into three development modes, namely, state-owned (mainstream) mode, business model (state-owned), business model and so on, which are different from the focus of content attribute and operation system. And art models, these models are intertwined, mixed, to meet the increasingly diverse cultural demands and a wide range of social needs.

\section{Film and television culture heritage and development under the strategy of One Belt and One Road}

These works have the inherent national character, national temperament, national culture and external customs, folk customs and so on. In a sense, these works full of national growth history and national cultural heritage. Different countries' political system and economic development speed are different, different countries and regions must be different in the cultural transmission, which also shows that countries and regions of the cultural diversity and diversity. Different nationalities, due to different social life, regional environment and ethnic, psychological structure and cultural awareness are bound to be unique. National film and television works in the overseas dissemination process, there will be a "cultural discount" phenomenon. "One Belt and One Road" strategy emphasizes the "three communion" concept, referring to sharing, build, win-win situation, the principle is open and inclusive. This requires us to rely on geographical advantages, and "One Belt and One Road" along the different countries, different ethnic groups more frequent and close communication, dissemination of outstanding national culture, to achieve the intersection of national cultures and integration. "The movie contains a variety of elements that current audiences like, such as treasure hunt, adventure, action, etc. It will be a cross-cultural, language, 
easy to understand the world's audience, like the movie, the film, Also can reflect the two ancient civilizations in ancient China has a long history of cultural exchanges and the legendary stories and cultural landscape. "Like Chinese movies in the martial arts and rivers and lakes culture, Indian film singing and dancing, Korean film gentle and gentle, are Showing their regional characteristics and history and culture.

"One Belt and One Road" strategy for our national film and television works "going out" has brought opportunities, is conducive to enhancing national cultural exchanges. We must proceed from the historical status and cultural life of each country, in-depth analysis of the local customs, customs, aesthetic taste and other factors, but also take into account the national film and television works for the film and television culture acceptance. Different strategies for different groups, concerned about their acceptance of psychology, looking for their concern "point of interest" and targeted its "point of interest" remedy, the creation for more audiences, multiple film and television culture film. At this level, we must grasp the perspective of narrative ethics of various countries, the organic integration of national elements in film and television works, better dissemination of Chinese culture, improve Chinese cultural soft power.

In the context of globalization, McLuhan in the 20th century, 60 years proposed the "global village" has gradually come true, people are increasingly dependent on the media. Film and television works because of its strong ideographic system by the different nationalities and cultural identity of the people. Chinese movie box office accounted for $17.7 \%$ of the global total box office, ranking second in the world. From the data can be concluded that Chinamade overseas sales of films with the "One Belt and One Road" strategy to increase the implementation, but the total revenue in the annual box office accounted for less, there is a big upgrade Space, and in the domestic film, the outstanding national film and television works and "going out" have become a problem. Europe and the United States has become the film industry, film and television production capacity, coupled with countries has their own film and television culture preferences, so that Chinese national film and television works difficult to enter other countries. In the "One Belt and One Road" under the influence of the strategy, along the country's population of 4.4 billion, the total economic output of 2.1 billion US dollars, which occupy a higher proportion of the world. While the core value of its interoperability, but also for Chinese national film and television trade to provide new opportunities.

In the future, according to the development of countries along the "One Belt and One Road" strategy, the dissemination of national film and television culture should formulate a more reasonable dissemination rules and systems, pay attention to the output of government culture, spread the region, to determine a breakthrough. For example, joint international film festivals, co-productions of films, and cooperation in the development of national film and television talent, and other effective measures to gradually improve the national film and television works of originality and output, in order to truly achieve "cultural stage, the economy Singing "a new pattern. 


\section{Film and television culture under the creative strategy of One Belt and One Road}

In China, creativity is often expressed in the limited subject matter and context to break through the conventional perspective and narrative techniques. In recent years, Indian directors Tassen Singh, Rakumar Hiram and Iranian directors Samira Mahamabhaf and Ahas Fahati have used their work to write the myth of national films Brought to a more modern and profound height, Central Asia and Eastern Europe, the film industry is booming. For example, the 2012 Iranian director Ahaz Fahadi's film "Once Parting: Nader and Westminster," including the Oscar for best foreign film award, including a number of international awards, and in China, including many A national release, the box office income is very impressive. This is a masterpiece to explore tradition and reality, faith and secularity, human nature and divinity, conservatism and change. The film reflects the dilemma and confusion faced by modern religious society through the contradiction of family.

Second, broaden the cultural expression and business narrative symbiotic ideas. On the ideological and commercial works of the isomorphism, we can see examples of Hollywood movies, "Devil" fashion "Island desert" "American Beauty" and other films have reached a balance between art and business, entertainment culture and serious Art in the film can be harmonious coexistence. Simply put, these three commercial elements of the film were: fashion, fantasy, comedy. The hidden reality and life is: human alienation and family conflicts in the commercial society. Hollywood writers and directors are familiar with the lens language packaging and narrative mechanisms, to profound philosophical implication in the humorous and vivid story, often need is the technology matures.

Third, the pursuit of film production to television, animation and other film and television production industry cluster development. At present, the construction of regional film base, talent and technology to play the cluster effect of a better idea of the industry, such as Hengdian Television City and other film bases have made no small achievement. In the "One Belt and One Road" strategy against the backdrop of the construction of film bases should be put on the agenda, not only about the integration of regional economic and cultural resources development, but also about whether to maximize the use of international channels to develop Chinese Film and television industry.

\section{Conclusion}

The implementation of "One Belt and One Road" strategy provides a rare opportunity for Chinese national film and television culture. Film and television art workers should fully grasp the opportunity to create more excellent works to serve the audience in the world. In the "One Belt and One Road" background, take the film as the media, pay attention to multi-ethnic film culture convergence 
and integration, national film and television trade exchanges and dissemination of Chinese and foreign cultural exchanges and spread a bridge.

\section{References}

[1] Wei Baoxiang, Ouyang Zhengyu. Film tourism: a new way of tourism destination marketing. Tourism Tribune, 55(12), pp.68-70, 2011

[2] Wang Lifo, Liu Hua. Analysis on the Promotion of Film and Television Culture to Tourist Destinations. Market Forum, 8 (5), pp.87- 91, 20013

[3] Fu Yan. Film and television culture extension - Analysis of film and television tourism development of the status quo and trend. Drama Literature. 12(10), pp. 18- 20, 2012

[4] Wu Pu, Ge Quansheng, Xi Jianchao, Liu Haolong.Study on the Formation and Development Mechanism of Film and Television Tourism. Tourism Tribune, 9(6), pp.58- 61, 2011

[5] Chen Ping. The film and television drama tourism destination marketing theory and practice. Journal of Guilin College of Tourism, 8(4), pp.85-87, 2014 